\title{
糖尿病患者にみられた突発難聴症例
}

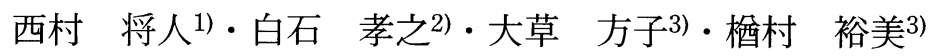 \\ 奥村 新一4) - 玉城 晶子5) - 久保 武3)
}

\section{Sudden Deafness in Patients with Diabetes Mellitus}

\author{
Masato Nishimura \\ (Sumitomo Hospital) \\ Takayuki Shiraishi \\ (Sakai Municipal Hospital) \\ Masako Okusa, Yumi Naramura and Takeshi Kubo
(Osaka University) \\ Shin-ichi Okumura \\ (Osaka Rosai Hospital) \\ Akiko Tamaki \\ (Kansai Rosai Hospital)
}

\begin{abstract}
A clinical study of auditory acuity and outcome was carried out in 27 patients with diabetes mellitus and sudden deafness. Although it has been believed that deafness first causes inability to hear high frequency sounds, the patients in this study, whose sensorineural hearing loss in each ear was compared, tended to lose the hearing of mid frequency sounds ( $500 \mathrm{~Hz}$ to $1 \mathrm{kHz}$ ) in particular. A further study of the influence of diabetes mellitus on auditory acuity and the relationship between examination results and outcome showed the following:(1) patients with advanced diabetic retinopathy tended to have little improvement of auditory acuity, (2) patients with proteinuria had significantly less improvement in hearing than did those with no proteinuria, (3) patients with high serum $\mathrm{HbA}_{1 \mathrm{c}}$ levels at the onset of deafness tended to have less improvement in hearing than did those with low levels, and (4) no correlation was noted between the duration of illness and the prognosis.
\end{abstract}

Key words : sudden deafness, diabetes mellitus, acute sensorineural hearing loss,

はじめに

糖尿病患者にみられる聴覚障害には，緩徐に進行する

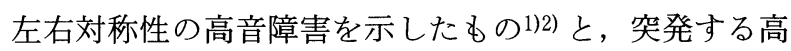
度の一側性または両側性の感音難聴を示したもの3) 5) が 報告されている，それらの原因としては，糖尿病の網膜
病変に類似した迷路，または聴神経の血管病変が推測さ れている122).

突発する高度の一側性または両側性の感音難聴に関す る報告は, 糖尿病が罹患数の多い疾患であるにも関わら ず，少数例のものが多く，まとまった報告はあまり行わ
1) 住友病院耳鼻咽喉科

3) 大阪大学医学部耳鼻咽喉科学教室

5）関西労災病院耳鼻咽喉科
2) 市立堺病院耳鼻咽喉科

4) 大阪労災病院耳鼻咽喉科 
れていない，その中で比較的多症例の報告としては, 設 楽ら3) の22例，中村ら4) の11例が挙げられるが，それら 飞扔いても, 通常経験する突発性難聴と臨床症状との間 には差はなく，糖尿病との関係は明らかにされていない。

しかし, 突発性難聴の病因の 1 つとして血管病変が古 くから考光られており年，糖尿病にみられる突発性の感 音難聴は，臨床的に興味深いものと思われる，そこで今 回，多施設に扮いて症例を蓄積し，此較的症例数の多い 27症例について，その特徴などについて検討したので報 告する.

\section{対象と方法}

(1) 対 象

対象は，1985年から1993年の 9 年間に大阪大学耳鼻咽 喉科と，1990年より1993年の 4 年間に関連病院 4 施設を 受診した 27 例 27 耳である(表 1 )。年齢は20歳から69歳, 平均年齢は57.7歳で，性別は男性17名・女性10名で男性 に多くみられた。 また全例一側性で，患側は右16例，左

\section{表 1 症例一覧}

\begin{tabular}{ccccccc}
\hline \hline 症例 & 年齢 & 性別 & 患側 & 耳鵬 & めま & 経過日数(日) \\
1 & 68 & 男 & 左 & + & + & 11 \\
2 & 61 & 男 & 右 & + & + & 2 \\
3 & 58 & 男 & 左 & + & - & 3 \\
4 & 53 & 男 & 左 & + & - & 5 \\
5 & 69 & 女 & 右 & + & + & 5 \\
6 & 57 & 女 & 左 & - & - & 3 \\
7 & 49 & 女 & 右 & - & - & 1 \\
8 & 40 & 男 & 左 & - & - & 2 \\
9 & 62 & 男 & 左 & + & - & 5 \\
10 & 67 & 男 & 右 & - & - & 2 \\
11 & 50 & 男 & 右 & - & + & 6 \\
12 & 20 & 女 & 右 & + & + & 10 \\
13 & 37 & 女 & 右 & + & - & 4 \\
14 & 68 & 男 & 左 & - & - & 1 \\
15 & 65 & 男 & 左 & + & - & 6 \\
16 & 66 & 男 & 左 & + & - & 2 \\
17 & 59 & 男 & 右 & + & - & 7 \\
18 & 56 & 女 & 右 & - & - & 0 \\
19 & 66 & 男 & 右 & - & - & 2 \\
20 & 63 & 女 & 右 & + & - & 4 \\
21 & 66 & 女 & 右 & + & - & 1 \\
22 & 64 & 女 & 右 & + & - & 3 \\
23 & 53 & 男 & 左 & + & - & 5 \\
24 & 56 & 男 & 左 & + & + & 3 \\
25 & 51 & 男 & 左 & + & - & 2 \\
26 & 57 & 男 & 右 & + & - & 5 \\
27 & 60 & 女 & 右 & + & - & 2
\end{tabular}

11例であった．耳鳴を伴った症例は19例 (70.4\%)で，め まいを伴った症例は 6 例 $(22.2 \%)$ であった，発症から治 療開始までの平均日数は3.8日で, インシュリン非依存 型糖尿病 (NIDDM) が26例, インシュリン依存型糖尿病 (IDDM) が 1 例(症例12) であった。糖尿病に伴ら突発難 聴では，数日間かけて進行する症例が，一般的な突発性 難聴より頻度が高いといら報告がある4)。今回の検討で は, 初診時聴力が悪化したものは27症例の内, 2 例 (7.4 \%)であった(症例16，25).

\section{(2) 検討項目}

以下の諸点について検討した.

1) 初診時聴力レベル

2 ）初診時聴力型

3 ）糖尿病性網膜病変と改善率

4 ）糖尿病性腎症と改善率

5 ）へモグロビン $\mathrm{A}_{1 c}$ 值と改善率

6 ）治療成績

（3）治療方法

糖尿病を合併する症例の場合，ステロイド剤の使用が 難しく, 治療に苦淽するところである. 我々は以前より 末梢循環改善剂による突発性難聴の治療について報 告7) 9) しているが，今回もバトロキソビン製剂を中心 とした modified defibrinogenation therapy ${ }^{10)}$ を用いた。 止血機能は全例正常であったが，眼底出血の既往がある ものはステロイド剤を内科との共同観察にて慎重な管理 下で使用した.

（4）予後の判定

予後の判定には以下の $2 つ の$ 判定基準を用いた.

(1)厚生省班研究による予後分類(昭和59年改定)を用い た判定 ${ }^{11}$

(2)改善率 $(\%)=($ 初診時聴力レベルー固定時聴力レベ ル) $\div$ (初診時聴力レベルー健側聴力レベル) $\times 100$

※聴力レベルは $125 \mathrm{~Hz}-8 \mathrm{kHz}$ の 7 周波の平均值を用 いた.

（1）初診時聴力レベル

結果

表 2 に患側と対側の初診時の各周波数別の平均聴力レ ベルを示した. 患側耳の特徵として $500 \mathrm{~Hz}$ 以上の周波 数に拈いて, $70 \mathrm{~dB}$ 前後の值を示し, 特に $8 \mathrm{kHz}$ では $79 \mathrm{~dB}$ と高度の障害をみた。一方, 対側耳の聴力レベル では, $125 \mathrm{~Hz}$ から $4 \mathrm{kHz}$ までの周波数では $30 \mathrm{~dB}$ 以内 
表 2 初診時・固定時の各周波数の平均聴力

\begin{tabular}{lllllllll}
\hline \hline & $(\mathrm{Hz})$ & 125 & 250 & 500 & $1 \mathbf{k}$ & $2 \mathbf{k}$ & $4 \mathbf{k}$ & $8 \mathbf{k}$ \\
\hline & & & & & & & & \\
初診時患側聴力 & $(\mathrm{dB})$ & 57 & 66 & 74 & 69 & 69 & 72 & 79 \\
& & & & & & & & \\
初診時健側聴力 & $(\mathrm{dB})$ & 26 & 25 & 21 & 19 & 23 & 27 & 42 \\
固定時患側聴力 & $(\mathrm{dB})$ & 34 & 33 & 33 & 34 & 34 & 53 & 65
\end{tabular}

の平均值をとったが， $8 \mathrm{kHz}$ では，平均 $42 \mathrm{~dB}$ の聴力低 下をみた。対側耳の聴力を突発難聴発症前の患側耳の聴 力と仮定し, 初診時聴力レベルと健側聴力レベルの差を 各周波数別に図 1 に示したが，突発難聴による聴力低下 は算術的には $500 \mathrm{~Hz}-1 \mathrm{kHz}$ の中音域に最も著しくみら れる結果となった。

（2）初診時聴力型

初診時の聴力型分類では, 高音漸减型と水平型が各 6 例, 谷型が 5 例, 高音急墜型と低音障害型が各 3 例, 山

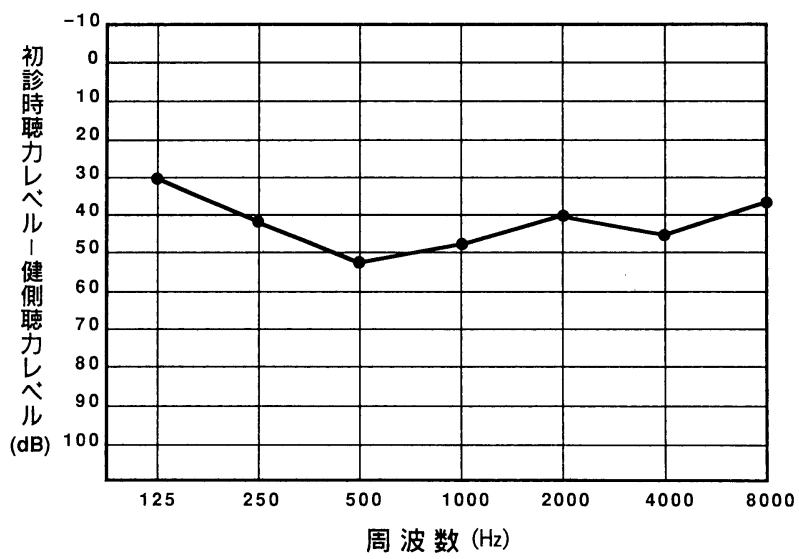

図 1 初診時聴力レベル一健側聴力レベル

表 3 初診時聴力型

\begin{tabular}{|c|c|}
\hline 低音障害型 & 3 例 \\
\hline 谷 & 5 例 \\
\hline 水 平 型 & 6 例 \\
\hline 高音急墜型 & 3 例 \\
\hline 高音漸減型 & 6 例 \\
\hline 山 & 2 例 \\
\hline 犃 & 2 例 \\
\hline
\end{tabular}

型と龍型が各 2 例と多彩な聴力型を示した（表 3 ).

（3）糖尿病性網膜病変と改善率

糖尿病性網膜症は 5 年以上の罹病者に多く, 10 年以上 で $50 \% ， 20$ 年以上になると $80 \%$ になり，発生頻度は主と して罹患年数と比例すると言われている12).

また糖尿病に上る網膜病変は現在，網膜に変化のみら れない non diabetic retinopathy (NDR) から, 単純型網 膜症 simple diabetic retinopathy (SDR), 増殖型網膜症 proliferative diabetic retinopathy (PDR) までの 3 つのス テージに分類されている.

今回の症例では25例が眼科医により診断され，その内 訳は NDR：13例, SDR：4 例, PDR：8 例であった(表 $4)$.

表 4 網膜病変と聴力

\begin{tabular}{|c|c|c|c|}
\hline & NDR & SDR & PDR \\
\hline 数 & 13 & 4 & 8 \\
\hline 初診時平均患側聴力 (dB) & 70 & 63 & 76 \\
\hline 初診時平均対側聴力 (dB) & 23 & 26 & 22 \\
\hline
\end{tabular}

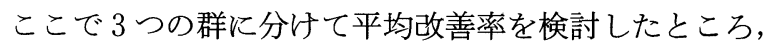
表 4 に示すように各群に有意差はなかったが，図 2 に示 すように NDR 群が $71.2 \%, \mathrm{SDR}$ 群が58.5\%, PDR 群 が $51.0 \%$ と低下傾向を示した.

（4）糖尿病性腎症と改善率

糖尿病性腎症との関係をみるため, 蛋白尿の有無と改 善率との関係を検討した，初診時に蛋白尿がみられたも のは 7 例 (25.9\%) であった(表 5 ). 両群の改善率を比較 してみると，蛋白尿の無い群の平均改善率が75.8\%だっ たのに対し, 蛋白尿がみられた群では $44.7 \%$ と改善率が 低く， 2 群間に有意な差がみられた（図 3$)(\mathrm{p}<0.05 ， \mathrm{t}$ - 


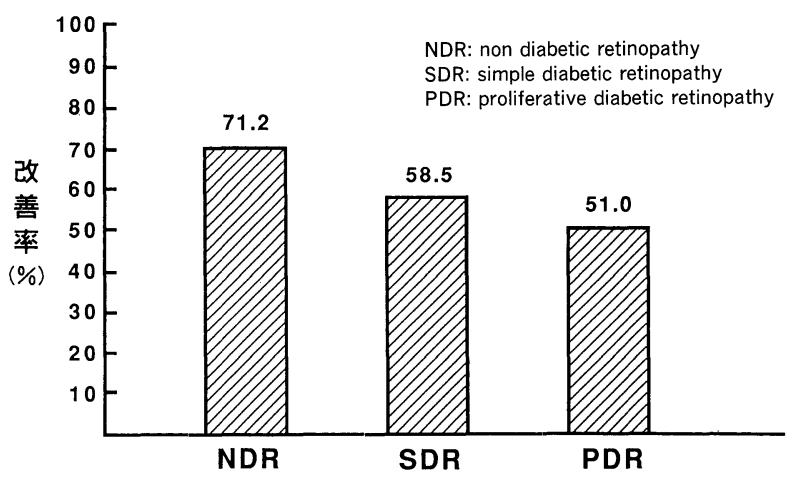

図 2 網膜病変と改善率の関係

表 5 蛋白尿の有無と聴力

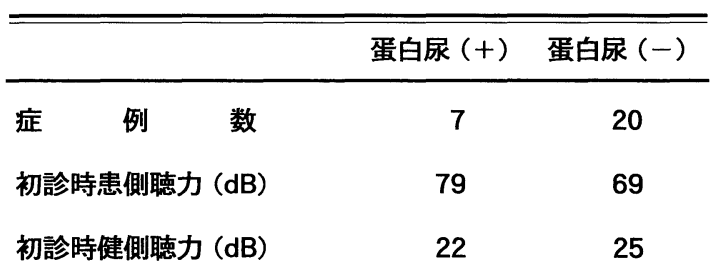

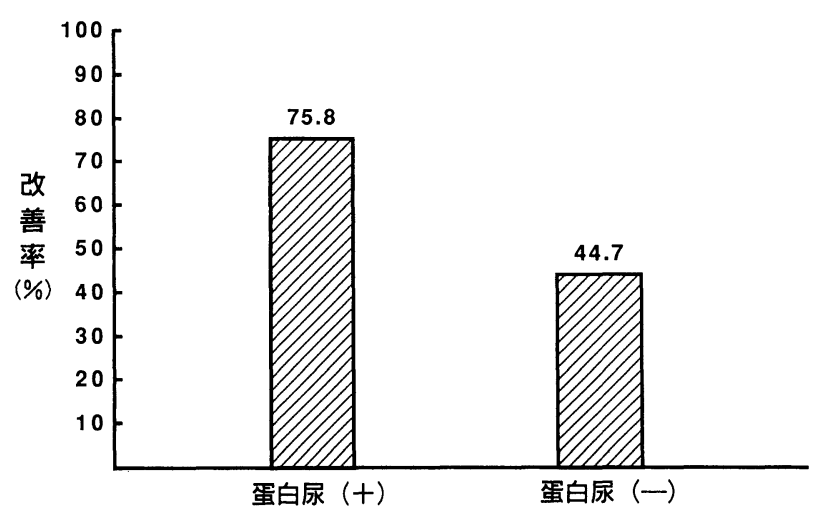

図 3 蛋白尿と改善率の関係

検定).

（5）へモグロビン $\mathrm{A}_{1 \mathrm{c}}$ 值と改善率

へモグロビン $\mathrm{A}_{1 \mathrm{c}}$ (以下 $\mathrm{HbA}_{1 \mathrm{c}}$ と略す)はグリコシル 化血色素の主要分画成分で, 約 3 力月間の血糖値の指標 と言われている．そこで, $\mathrm{HbA}_{1 \mathrm{c}}$ の值と改善率の関係 について検討した。図 4 亿示すように, $\mathrm{HbA}_{1 \mathrm{c}}$ の值が 高いもの汪ど改善率が低下する傾向がみられた.

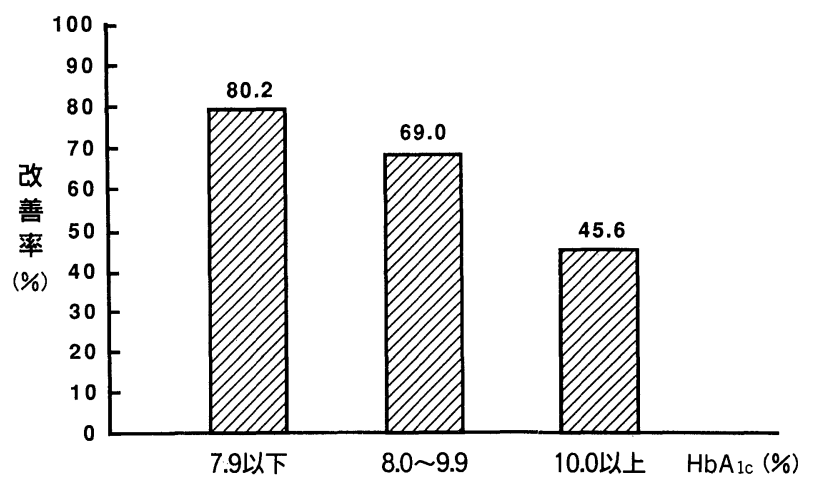

図 $4 \quad \mathrm{HbA}_{1 \mathrm{C}}$ 之改善率の関係

表 6 厚生省班研究による予後分類 ${ }^{11)}$

\begin{tabular}{lrr}
\hline \hline 治 & 癒 & 10 例 \\
著 & 明 回 復 & 7 例 \\
回 & 復 & 6 例 \\
不 & 変 & 4 例
\end{tabular}

（6）治療成績

厚生省班研究による予後分類11) では, 治癒: 10例, 著明回復 : 7 例, 回復 : 6 例, 不変 : 4 例で, 著明回復 以上が計 17 例 $63.0 \%$ と良好な治療成績が得られた(表 6 ). 改善率を用いた判定では平均改善率は68.4\%であり， 各周波数別の平均改善率をみると $4 \mathrm{kHz} \cdot 8 \mathrm{kHz}$ の改善 率は, $2 \mathrm{kHz}$ 以下の改善率に比べ低く, 高音部の回復が 難しいことがわかった（図 5 ).

\section{考察}

糖尿病の定義は, “慢性的な高血糖状態であり, 糖代 謝, 蛋白, ならびに脂質代謝の異常を招き, 腎蔵や網膜 など細血管の異常を，あるいは末梢神経の損傷を引き起 こす” 血管・神経の慢性合併症を含めた一連の疾患群と されている.

一方, 糖尿病患者に拈ける聴力障害の報告は，1857年 の Jordao ${ }^{13)}$ の報告以来いくつか散見されるが，高音漸 減型や高音急墜型など高音障害が多く，糖尿病のコント ロールが不良のものや, 網膜症や腎症を伴らものに高度 な難聴や予後不良例が多い傾向にあるとする意見が多く みられる。

その病理組織学的検討では, 血管条, 内耳道内血管, 


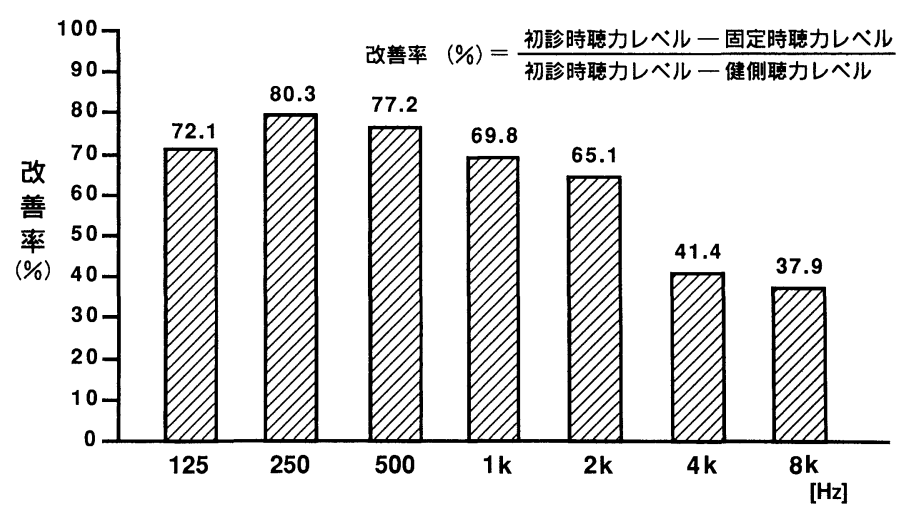

図 5 各周波数別聴力改善率

有毛細胞などの異常が側頭骨病理標本やNIDDM モデ ルラットにて報告されている2)14)15).

今回，健側耳聴力をふまえて検討したが，突発難聴は 高音障害を特徵とするといらょりも，両側耳が，年齢変 化にみられるよらな高音漸減型の感音難聴を発症以前に もち，実際の聴力低下は広い周波数にわたるといら結果 であった。

Jorgensen ${ }^{2)}$ は眼底出血と同時に発症した突発難聴を 報告し，この原因として網膜でみられる出血が内耳に起 こったためと推測して搞り，他の過去の報告4)16)でも網 膜症と聴力障害の関係を有意とするものが多い，今回の 検討でも網膜血管病変が高度な群汪ど改善率の低下傾向 を示し, 血管病変の進行の度合に, 予後が影響されると 考えられ，検討症例数の少なさを考慮しても，血管障害 が症例によってはその病因の 1 つであるとすることは自 然であろう．この為，原因が不明であるという定義の突 発性難聴と区別し, 突発難聴としている報告3)4) も多い.

そこで，次に腎臓での細血管障害である糖尿病性腎症 との関連を検討するため, 蛋白尿のみられる症例とみら れない症例を比較したところ，蛋白尿のみられた症例で 有意に改善率の低下がみられた。すなわら糖尿病性腎症 所見のみられる症例の平均改善率はみられない症例より も有意に低く，これも突発難聴の血管障害要因を示唆す る結果となった。しかし，中村ら年快尿蛋白の有無での 難聴の程度と予後に和いて, 有意差はみられなかったと して拈り，中等度の腎病変が存在しても蛋白尿をみない 症例も存在するため, 腎症の確定診断は腎生検によらな ければならず，今後微量蛋白の定量による検査などが必 要であろら.
網膜症や腎症はその糖尿病の罹病期間が 10 年を越えた ものに多くみられるようである。そこで今回罹病期間と 改善率についても検討したが，有意な傾向はみられなか った.これは今回の症例が 1 例を除き非インシュリン依 存型糖尿病 (NIDDM) であったため，その発症時期が不 明瞭で，中には耳鼻科での検査にてはじめて糖尿病を指 摘された症例もあるなど，罹病期間自体がはっきりしな い事もあり，罹病期間との検討は今後も難しいものと考 えられる。

耳鼻咽喉科領域の疾患で糖尿病を伴う時, ステロイド の使用が困難となり，その治療に苦慮する事は日常の診 療に拈いてたびたび経験するところである。森戸ら ${ }^{17)}$ は突発難聴の治療中に急性咽頭炎から頸部蜂窩織炎を引 き起こした症例を報告して括り，その他耐糖能の更なる 低下など，その使用には十分な注意が必要である。今回 の症例では 7 例でステロイド剤を内科との共同観察で使 用しているが，大きな副作用を引き起こした例はなかっ た. 過去の報告でもステロイド剤の使用を積極的に行ら べきとする報告4)18）もるが，今回の結果でも，きびし い管理下での使用は問題ないと考えられた。また，今回 20例で使用したバトロキソビン製剂は，易感染性や耐糖 能の低下といら問題がなく，糖尿病の突発難聴の治療に は有用と考劣られた。しかし，この薬㓮について主治医 が深い知識をもち，患者へのインフォームド・コンセン トが必要であることはいらまでもない。

$$
\text { まとめ }
$$

糖尿病を合併した突発難聴症例27例の聴力や子後につ いて検討した。聴力については以前より高音部に強い難 
聴と言われてきたが，対側聴力との差でみた場合，聴力 低下は $500 \mathrm{~Hz}-1 \mathrm{kHz}$ の中音域に強くみられた。糖尿病 の合併症や検查所見と予後の関係について検討したとこ ろ次のようなことがみられた。（1)糖尿病性網膜症が進 行した群では，聴力改善が悪い傾向がみられた（2)蛋 白尿のみられた群は蛋白尿のみられなかった群より聴力 改善が有意に悪かった. (3) 難聴発症時の $\mathrm{HbA}_{1} \mathrm{c}$ が高い 群の方が聴力改善が悪い傾向がみられた（4)糖尿病の 罹病期間と予後の間には相関をみなかった。

\section{参考文献}

1) 名越好古, 大下富美代, 早川浩市, 他 : 糖尿病者の聴力障 害(第 1 報). Audiology Japan $12: 155 \sim 159,1969$.

2 ) Jorgensen MB : Studies on inner-ear function and cranial nerve in diabetics. Acta Otolaryngol $53: 350 \sim 364,1961$.

3 ) 設楽哲也, 古沢慎一, 岡本牧人, 他: 糖尿病患者に及られ た突発難聴. 厚生省特定疾患急性高度難聴調查研究班 昭 和59年研究報告書. 91 95頁, 1984.

4 ) 中村雅一, 川端五十鈴：糖尿病患者にみられた突発難聴. Audiology Japan $34: 97 \sim 103,1991$.

5 ) De Kleyn A : Sudden complete or partial loss of function of the octavus-system in apparently normal person. Acta Otolaryngol 32 : 407 429, 1944.

6 ）切替一郎, 松崎 力: 突発性難聴の臨床的観察. 耳喉 39 : 1193 1200, 1967.

7 ）久保 武, 奥村新一, 白石孝之, 他 : 突発性難聴汶対する

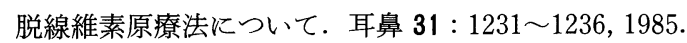

8 ）浅井英世, 久保 武, 白石孝之, 他: 突発性難聴见対する 脱線維素原療法と既存療法との比較検討. 臨床医薬 1: 1189 1199, 1985.
9) 西村将人, 白石孝之, 久保 武, 他: 脱線維素療法を用い た突発性難聴の治療. 平成 2 年度特定疾患調查研究結果報 告書. 15 19頁, 大阪府環境保健部, 1991.

10) Shiraishi $T$, Nishimura $M$, Kubo $T$, et al : Hearing recovery in sudden deafness patients using a modified defibrinogenation therapy. Acta Otolaryngol Suppl (Stockh) $501:$ 46 50, 1993.

11）野村恭也：昭和 59 年度研究業續報告書. $1 \sim 4$ 頁, 厚生省 特定疾患急性高度難聴調查研究班, 1985.

12）松井瑞夫： I-1 糖尿病性網膜症. 新糖尿病 (池田義雄編). 21頁，株式会社日本メディカルセンター，東京，1986.

13) Jordao AMD : Consideration surun cas du diabete. Un med Paris $11: 446 \sim 450,1857$.

14）牧島和見：糖尿病患者の難聴の臨床病理. 日耳鼻 74 : 1099 1102, 1971.

15) Kevin RR : Inner ear damage secondary to diabetes mellitus. Arch Otolaryngol Head Neck Surg $118:$ 397 400, 1992.

16）丸毛和男, 藤井 暁, 鹤崎正治, 他: 糖尿病患者に括沪る 聴力障害に関する臨床的検討. 糖尿病 $27: 1105 \sim 1113$, 1984.

17）森戸佳代子, 横田 明 : 突発性難聴治療中に重症感染症を ひき扮こした糖尿病患者の一例. 名古屋市立病院紀要 9: $107 \sim 110,1986$.

18）森 慶人, 都築 賢, 伴野 啓, 他: 糖尿病に合併した両 側性突発性難聴の一症例. 耳鼻臨床 $78: 637 \sim 642,1985$.

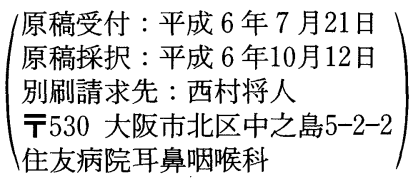

